\title{
Restriction fragment length polymorphism analysis of major histocompatibility complex genes in the non-obese diabetic mouse strain and its non-diabetic sister strains
}

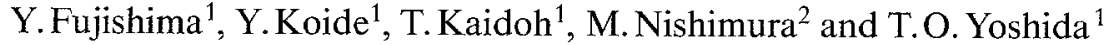 \\ ${ }^{1}$ Department of Microbiology and Immunology, and \\ ${ }^{2}$ Institute for Experimental Animals, Hamamatsu University School of Medicine, Handa, Hamamatsu, Japan
}

\begin{abstract}
Summary. It has been suggested that one of the recessive genes controlling diabetes in non-obese diabetic mice is linked to the major histocompatibility complex. We, therefore, performed restriction fragment length polymorphism studies of major histocompatibility complex genes (class I, II, and III) in nonobese diabetic mice in comparison with those of their nondiabetic sister strains, non-obese non-diabetic, cataract, and ILI mice which were derived from the same Jcl-ICR mice as the non-obese diabetic mouse was. When class II and III probes and a minimum of four restriction enzymes were used, class II and III genes of non-obese diabetic mice were indistinguishable from those of cataract and ILI mice but totally different from those of non-obese non-diabetic mice. The studies also indicated that $A \beta, E \beta$, and C4-Slp genes of nonobese diabetic, cataract, and ILI mice, and $\mathrm{A} \alpha, \mathrm{A} \beta, \mathrm{E} \beta$ and C4-Slp genes of non-obese non-diabetic mice are different from those of $\mathrm{BALB} / \mathrm{c}$ and $\mathrm{C} 57 \mathrm{BL} / 6$ mice, respectively. While non-obese non-diabetic mice expressed the $\mathrm{E} \alpha$ gene, non-obese diabetic, cataract, and ILI mice appeared to carry a deletion in the $5^{\prime}$ end of the E $\alpha$ gene resulting in failure to
\end{abstract}

transcribe the E $\alpha$ gene. When class I probe was used, cataract mice showed very different band patterns from those of the other ICR-derived mice. It is suggested that non-obese diabetic, non-obese non-diabetic, and ILI mice contain only a single class I D region gene. Taken together, these results indicate that, although class I loci of non-obese diabetic and ILI mice were serologically typed as $\mathrm{K}^{\mathrm{d}}$ and $\mathrm{D}^{\mathrm{b}}$, and those of nonobese non-diabetic mice were typed as $\mathrm{K}^{\mathrm{b}}$ and $\mathrm{D}^{\mathrm{b}}$, no $\mathrm{H}-2^{\mathrm{g}}$ type recombination between $\mathrm{K}$ and $\mathrm{D}$ loci of non-obese diabetic, cataract, and ILI mice was evident. Since cataract and ILI mice are suggested to share the same class II and III regions with non-obese diabetic mice, they should be feasible strains for further studies to characterise the major histocompatibility complex-linked diabetogenic gene(s) of the nonobese diabetic mouse strain.

Key words: Major histocompatibility complex, non-obese diabetic mouse, non-obese non-diabetic mouse, cataract mouse, ILI mouse, insulin-dependent diabetes, restriction fragment length polymorphisms.
The non-obese diabetic (NOD) mouse strain spontaneously develops insulin-dependent diabetes mellitus. The disease is presumed to be of autoimmune etiology since it is characterised by lymphocyte infiltration into the pancreatic islets (insulitis) [1-4], autoantibodies against islet cells $[3,5]$, and the ability of the disease to be transferred to NOD nu/nu mice by splenic lymphocytes of NOD mice [6]. In breeding studies with NOD and $\mathrm{C} 57 \mathrm{BL} / 6$ mice, it has been revealed that two recessive genes on independent chromosomes are responsible for the insulitis [7]. In crosses of NOD mice with normal $\mathrm{C} 3 \mathrm{H}$ mice, Hattori et al. [8] detected a recessive diabetogenic gene linked to the major histocompatibility complex (MHC). In separate reports $[9,10]$, it has been suggested that at least three recessive genes, including one linked to the $\mathrm{MHC}$, control the develop- ment of diabetes in NOD mice. From the cDNA sequencing studies, Acha-Orbea and McDevitt [11] suggested that the unique sequence of I-A $\beta$ allele in NOD mice may make the $A \beta$ gene the MHC-linked susceptibility gene. Nishimoto et al. [12] reported that the expression of I-E molecules in NOD rnice can prevent the development of insulitis and suggested that the failure of the E $\alpha$ gene expression, in concert with other recessive gene(s) controlling insulitis, allows NOD mice to develop insulitis. However, precise characterisation and localisation of the MHC-linked diabetogenic gene(s) in NOD mice have been not yet determined. Therefore, further studies of MHC genes in the NOD mouse and its sister strains provide very useful information to characterise MHC-linked diabetogenic gene(s) in NOD mice. 

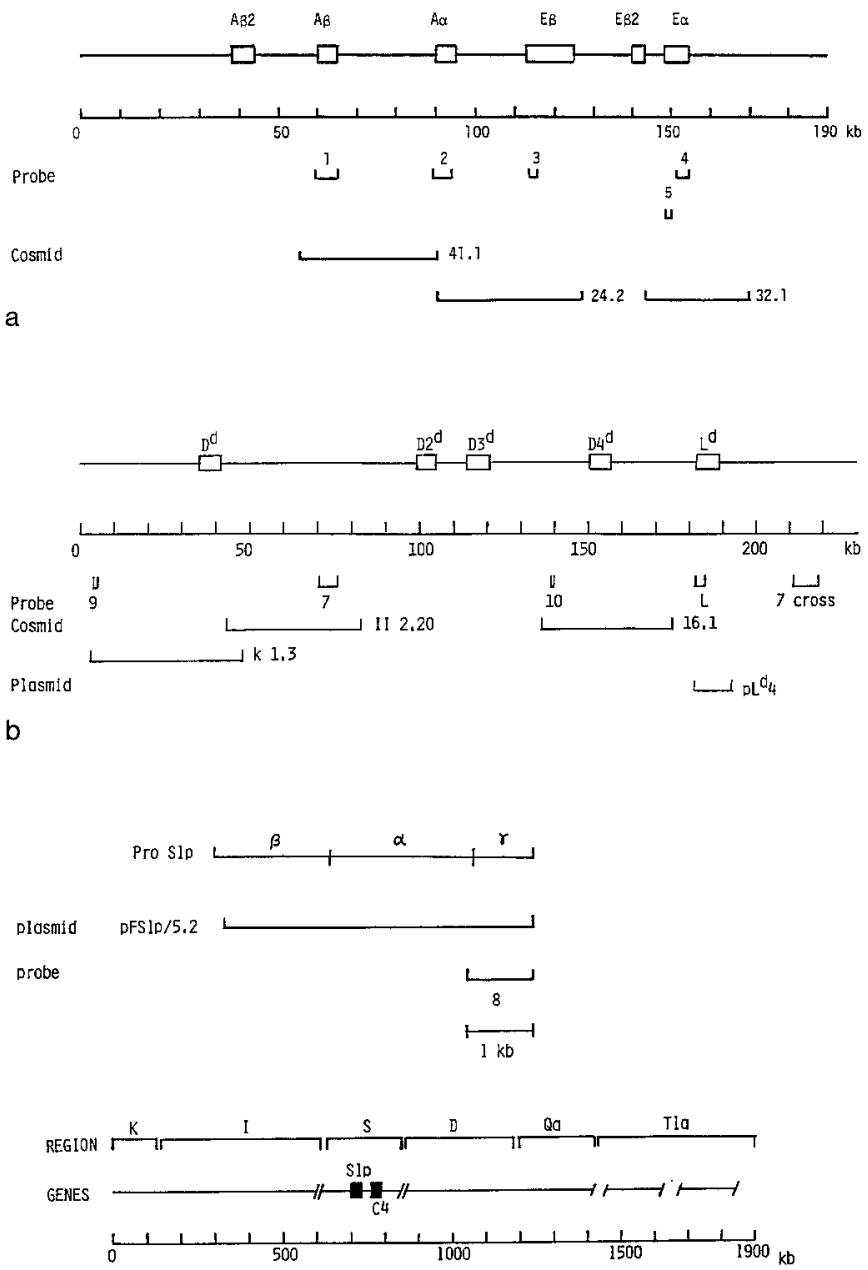

c

Fig. 1. Schematic map of the major histocompatibility complex (MHC) genes. a Class II region and hybridisation probes for restriction fragment length polymorphism (RFLP) analysis of class II genes (adapted from Steinmetz et al. [13]). Genes are shown as open boxes (). b Class I region and hybridisation probes for RFLP analysis of class I genes. Genes are shown as open boxes $(\square)$. The "7 cross" indicates a sequence that cross-hybridises strongly with probe 7 (adapted from Stephan et al. [14]). c Class III region and hybridisation probes for RFLP analysis of class III genes (adapted from Nonaka et al. [16]). Genes are shown as closed boxes (

In this study, we have performed restriction fragment length polymorphism (RFLP) studies of MHC genes (class I, II, and III) in NOD mice in comparison with those of non-obese non-diabetic (NON), cataract (CTS), and ILI mice, which are non-diabetic inbred strains but are derived from the same Jcl-ICR mice as NOD mice was.

\section{Materials and methods}

\section{Mouse strains}

NOD, NON, BALB/c, and C57BL/6 mice were bred in our Institute for Experimental Animals. CTS mice were kindly provided for a preparation of DNA and RNA by Dr. S. Makino (Aburahi Laboratory, Shionogi, Shiga, Japan). ILI mice were kindly provided by Dr.

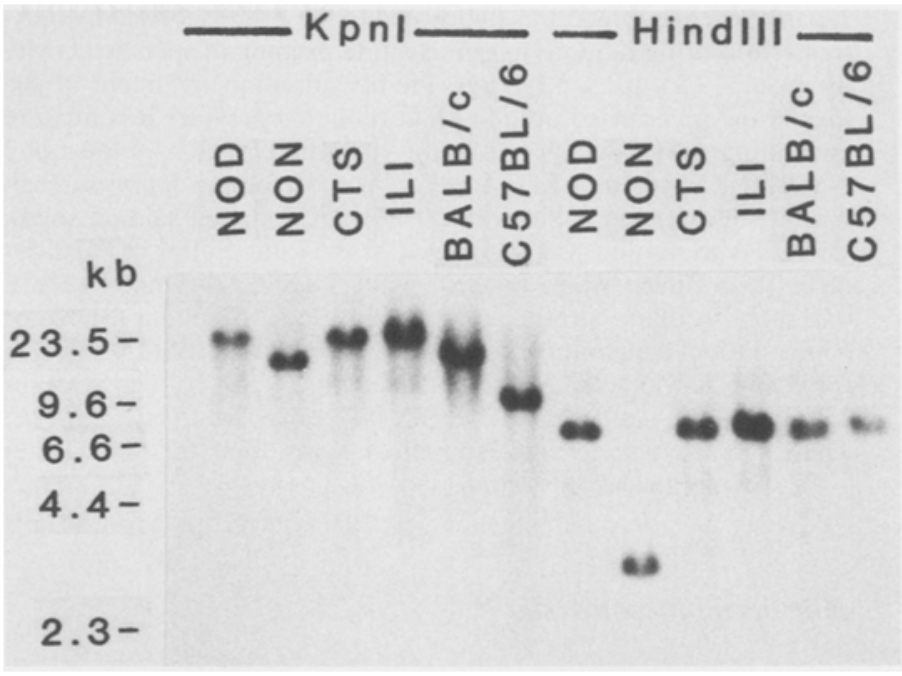

Fig. 2. Southern blot analysis of ICR-derived mice DNA with class II probe $3(\mathrm{E} \beta)$ after digestion with $\mathrm{Kpn} \mathrm{I}$ or Hind III. Ten $\mu \mathrm{g}$ of enzyme-digested DNA per lane was run on $0.7 \%$ agarose gels, blotted, and hybridised with the probe. Sizes of DNA marker fragments are shown at the left of the figure

H.Kato (Central Institute for Experimental Animals, Kawasaki, Japan). The NOD and NON strains were established in the course of the establishment of the CTS mouse strain from commercial outbred Jcl-ICR mice [1]. The ILI strain was also established from Jcl-ICR mice in Central Institute for Experimental Animals (Kawasaki, Japan).

\section{DNA probes}

The hybridisation probes were derived from the following cosmid clones isolated from $\mathrm{BALB} / \mathrm{c}$ or AKR DNA libralies [13, 14]. Class II MHC probes (Fig.1-(a)): Probe 1 (Aß) $5.2 \mathrm{~kb}$ Eco RI fragment from 41.1; probe $2(\mathrm{A \alpha}), 4.7 \mathrm{~kb}$ Eco RI-Bam HI fragment from 24.2; probe $3(\mathrm{E} \beta), 2.0 \mathrm{~kb}$ Eco RI fragment from 24.2; probe 4 (5' probe of $\mathrm{E} \alpha), 3.4 \mathrm{~kb}$ Sal I fragment from 32.1 ; probe 5 ( $3^{\prime}$ probe of $\left.\mathrm{E \alpha}\right), 1.6 \mathrm{~kb}$ Sal I-Sma I fragment from 32.1 ; probe $6,0.4 \mathrm{~kb}$ Acc I-Sac I fragment (the sequence spanning the promoter region and the signal peptide exon of the $\mathrm{E} \alpha^{\mathrm{d}}$ gene) from 32.1. Class I D region probes (Fig. 1-(b)): probe $7,6.2 \mathrm{~kb} \mathrm{Hpa} \mathrm{I}$ fragment (the region between $\mathrm{D}^{\mathrm{d}}$ and $\mathrm{D}_{2}{ }^{\mathrm{d}}$ genes) from II 2.20 ; probe $9,0.8 \mathrm{~kb} H \mathrm{Hpa}$ I fragment ( $5^{\prime}$ flanking sequences of the $\mathrm{D}^{\mathrm{k}}$ gene) from $\mathrm{k} 1.3$; probe $10,0.6 \mathrm{~kb}$ Dpn I fragment (the segment between $\mathrm{D}_{3}{ }^{\mathrm{d}}$ and $\mathrm{D}_{4}{ }^{\mathrm{d}}$ genes) from the $5.2 \mathrm{~kb}$ Nru I-Sma I fragment of 16.1. These class II and class I region cosmid clones were kindly provided by Dr. M. Steinmetz (Basel Institute for Immunology, Basel, Switzerland). Class I MHC probe (Fig.1-(b)): probe L is a $1.6 \mathrm{~kb}$ Xba I fragment ( $5^{\prime}$ half of the coding region of the $\mathrm{L}^{\mathrm{d}}$ gene) from genomic clone $\mathrm{pL}^{\mathrm{d}}-4$ [15] which was kindly provided by Dr. T.Shiroishi (National Institute of Genetics, Mishima, Japan). Class III MHC probe (Fig.1-(c)): probe 8 is "sex-limited protein (Slp)" $\gamma$ chain cDNA, isolated from cDNA clone $\mathrm{pFSlp} / 5.2$ [16] which was kindly provided by Dr. M.Takahashi (Department of Immunobiology, Cancer Research Institute, Kanazawa University, Kanazawa, Japan).

\section{Southern blot analysis}

The procedure used was adapted from the protocol of Nasmyth [17]. Genomic DNA $(10 \mu \mathrm{g})$ from mouse spleens or testes was digested with restriction enzymes, and was electrophoresed in a $0.7 \%$ agarose gel, and transferred to Hybond $\mathrm{N}$ nylon filters (Amersham, Tokyo, 
Japan). The membrane was hybridised to the probe labelled by nicktranslation or by random hexanucleotide priming (a specific activity of about $1 \sim 3 \times 10^{8}$ c.p.m. $/ \mu \mathrm{g}$ ). Pre-hybridisation treatment of the membrane was carried out for $1 \mathrm{~h}$ at room temperature in a mixture containing $54 \%$ Nasmyth solution $(0.55 \mathrm{~mol} / \mathrm{l} \mathrm{NaCl}, 0.166 \mathrm{~mol} / \mathrm{l}$ $\mathrm{Na}_{2} \mathrm{HPO}_{4}, 5.5 \mathrm{mmol} / 1$ EDTA pH 6.2, $1.85 \%$ sodium lauryl sarcosinate, $18.5 \%$ dextran sulfate) and $0.46 \%$ of $10 \mathrm{mg} / \mathrm{ml}$ salmon sperm DNA. Hybridisation was performed in the same buffer at $65^{\circ} \mathrm{C}$ for $48 \mathrm{~h}$. The filters were washed with $3 \times \mathrm{SSC}(0.3 \mathrm{~mol} / 1 \mathrm{NaCl}$, $0.03 \mathrm{~mol} / 1$ sodium citrate), $0.1 \%$ sodium dodecyl sulfate (SDS) for $5 \mathrm{~min}$ at room temperature and then washed with $2 \times \mathrm{SSC}, 0.1 \%$ SDS for $5 \mathrm{~min}$ at room temperature, and with $1 \times \mathrm{SSC}, 0.1 \%$ SDS for $15 \mathrm{~min}$ at $68^{\circ} \mathrm{C}$, and with $0.2 \times \mathrm{SSC}, 0.1 \%$ SDS for $15 \mathrm{~min}$ at $68^{\circ} \mathrm{C}$. The filters were dried and exposed to $\mathrm{X}$-ray films for 3-4 days at $-70^{\circ} \mathrm{C}$ with intensifying screen.

\section{Northern blot analysis}

Twenty $\mu \mathrm{g}$ of total RNA prepared from mouse spleens by the guanidinium-isothiocyanate method [18] was electrophoresed on a $1.0 \%$ agarose formaldehyde gel, and transferred to Hybond $\mathrm{N}$. The membrane was hybridised to a ${ }^{32}$ P-labelled nick-translated probe in a mixture containing 54\% Nasmyth solution [17], $46 \%$ formamide and $0.46 \%$ of $10 \mathrm{mg} / \mathrm{ml}$ Salmon sperm DNA for $24 \mathrm{~h}$ at $37^{\circ} \mathrm{C}$. After hybridisation, the filters were washed down to $0.2 \times \mathrm{SSC}$ at $68^{\circ} \mathrm{C}$, dried, and exposed to X-ray films.

\section{Statistical analysis}

RFLP analysis using class I probe $\mathrm{L}$ was evaluated by the percentage of coincidence of RFLP to NOD DNA. The formula for this calculations as follows: percent coincidence of $\mathrm{RFLP}=(1-$ discordant band number to NOD of test DNA/total fragment number detected in mice studied with probe L) $\times 100$.

\section{Results}

Restriction fragment length polymorphism analysis using class II major histocompatibility complex probes

Mouse strains established from Jcl-ICR mice, NOD $\left(\mathrm{K}^{\mathrm{d}}, \mathrm{D}^{\mathrm{b}}\right)$, NON $\left(\mathrm{K}^{\mathrm{b}}, \mathrm{D}^{\mathrm{b}}\right)$ (K. Moriwaki, personal communication), CTS (?), and ILI $\left(\mathrm{K}^{\mathrm{d}}, \mathrm{D}^{\mathrm{b}}\right)$ and the two mouse strains $\mathrm{BALB} / \mathrm{c}\left(\mathrm{H}-2^{\mathrm{d}}\right)$ and $\mathrm{C} 57 \mathrm{BL} / 6\left(\mathrm{H}-2^{\mathrm{b}}\right)$ were analysed for RFLP of class II genes. BALB/c and $\mathrm{C} 57 \mathrm{BL} / 6$ mice were chosen as control strains since the class I loci of the NOD mouse have been typed serologically as $\mathrm{K}^{\mathrm{d}}$ and $\mathrm{D}^{\mathrm{b}}$. The genomic loci of each probes are shown in Figure 1-(a). We chose these probes because RFLP patterns in various MHC haplotypes of mouse strains have been reported using them and restriction enzymes, Eco RI, Bam HI, Hind III, and Kpn I [13, 19]. The results are presented in Table 1. Southern blot analysis using probe 3 (Eß) with Kpn I and Hind III is illustrated in Figure 2. With probe 1 $(A \beta)$, RFLP patterns of NOD, CTS, and ILI DNA were indistinguishable, but NON mice showed quite different band patterns from the other three ICR-derived
Table 1. Results of restriction fragment length polymorphism analysis using class II major histocompatibility complex probes

\begin{tabular}{|c|c|c|c|c|c|c|c|c|c|}
\hline \multirow{2}{*}{$\begin{array}{l}\text { Probe } 1 \\
\text { mouse } \\
\text { strain } \\
\text { NOD }\end{array}$} & \multirow{2}{*}{$\begin{array}{l}\mathrm{H}-2 \\
\mathrm{~g}\end{array}$} & \multirow{2}{*}{$\begin{array}{c}\text { Eco RI } \\
6.6^{\mathrm{a}}\end{array}$} & \multicolumn{2}{|c|}{ Bam HI } & \multicolumn{4}{|c|}{ Hind III } & \multirow{2}{*}{$\begin{array}{r}\text { Kpn } \\
13\end{array}$} \\
\hline & & & 12.5 & 2.7 & & 6.4 & 5.5 & 1.9 & \\
\hline NON & $\mathrm{b}$ & 7.0 & 9.6 & 2.7 & 2.3 & 8.2 & & & $>30$ \\
\hline CTS & $?$ & 6.6 & 12.5 & 2.7 & & 6.4 & 5.5 & 1.9 & 13 \\
\hline ILI & g & 6.6 & 12.5 & 2.7 & & 6.4 & 5.5 & 1.9 & 13 \\
\hline $\mathrm{BALB} / \mathrm{c}$ & $\mathrm{d}$ & 6.6 & 12.5 & 2.7 & & 6.4 & 2.8 & 1.9 & $>30$ \\
\hline C57BL/ 6 & b & 7.0 & 9.6 & 2.3 & & 8.2 & 4.7 & & $>30$ \\
\hline
\end{tabular}

\begin{tabular}{|c|c|c|c|c|c|}
\hline $\begin{array}{l}\text { Probe } 2 \\
\text { mouse } \\
\text { strain }\end{array}$ & $\mathrm{H}-2$ & Eco RI & Bam HI & Hind III & Kpn I \\
\hline NOD & $\mathrm{g}$ & 11.5 & 6.0 & 11.0 & 11.0 \\
\hline NON & b & 11.5 & 6.0 & 6.1 & 15.0 \\
\hline CTS & $?$ & 11.5 & 6.0 & 11.0 & 11.0 \\
\hline ILI & $\mathrm{g}$ & 11.5 & 6.0 & 11.0 & 11.0 \\
\hline BALB/c & d & 11.5 & 6.0 & 11.0 & 11.0 \\
\hline C57BL $/ 6$ & b & 11.5 & 6.0 & $8.2 \quad 1.3$ & 23.5 \\
\hline $\begin{array}{l}\text { Probe } 3 \\
\text { mouse } \\
\text { strain }\end{array}$ & $\mathrm{H}-2$ & Eco RI & Bam HI & Hind III & Kpn I \\
\hline NOD & g & 2.1 & 13.0 & 8.0 & 23.5 \\
\hline NON & $\mathrm{b}$ & 2.1 & 4.8 & 3.1 & 15.0 \\
\hline CTS & $?$ & 2.1 & 13.0 & 8.0 & 23.5 \\
\hline ILI & g & 2.1 & 13.0 & 8.0 & 23.5 \\
\hline $\mathrm{BALB} / \mathrm{c}$ & d & 1.9 & 5.5 & 8.0 & 15.0 \\
\hline $\mathrm{C} 57 \mathrm{BL} / 6$ & $\mathrm{~b}$ & 2.1 & 13.0 & 8.0 & 10.5 \\
\hline
\end{tabular}

\begin{tabular}{|c|c|c|c|c|c|c|c|}
\hline $\begin{array}{l}\text { Probe } 4 \\
\text { mouse } \\
\text { strain }\end{array}$ & $\mathrm{H}-2$ & \multicolumn{2}{|c|}{ Eco RI } & \multirow{2}{*}{$\begin{array}{l}\text { Bam HI } \\
7.47 .0\end{array}$} & \multirow{2}{*}{$\begin{array}{l}\text { Hind III } \\
7.2\end{array}$} & \multicolumn{2}{|c|}{ Kpn I } \\
\hline NOD & $\mathrm{g}$ & 8.4 & 3.0 & & & 8.6 & 3.0 \\
\hline NON & $\mathrm{b}$ & 9.6 & 3.0 & 7.4 & 8.1 & 8.6 & 3.7 \\
\hline CTS & $?$ & 8.4 & 3.0 & 7.47 .0 & 7.2 & 8.6 & 3.0 \\
\hline ILI & $\mathrm{g}$ & 8.4 & 3.0 & 7.47 .0 & 7.2 & 8.6 & 3.0 \\
\hline $\mathrm{BALB} / \mathrm{c}$ & d & 9.6 & 3.0 & 7.4 & 8.1 & 8.6 & 3.7 \\
\hline $\mathrm{C} 57 \mathrm{BL} / 6$ & b & 8.4 & 3.0 & 7.47 .0 & 7.2 & 8.6 & 3.0 \\
\hline $\begin{array}{l}\text { Probe } 5 \\
\text { mouse } \\
\text { strain }\end{array}$ & $\mathrm{H}-2$ & Eco & & Bam HI & Hind III & & pn I \\
\hline NOD & $\mathrm{g}$ & 7.6 & & 5.6 & 8.6 & & 3.2 \\
\hline NON & b & 8.4 & & 6.2 & 9.0 & & 4.0 \\
\hline CTS & $?$ & 7.6 & & 5.6 & 8.6 & & 3.2 \\
\hline ILI & $\mathrm{g}$ & 7.6 & & 5.6 & 8.6 & & 3.2 \\
\hline $\mathrm{BALB} / \mathrm{c}$ & d & 8.4 & & 6.2 & 9.0 & & 4.0 \\
\hline $\mathrm{C} 57 \mathrm{BL} / 6$ & $\mathrm{~b}$ & 7.6 & & 5.6 & 8.6 & & 3.2 \\
\hline
\end{tabular}

${ }^{\text {a }}$ Fragment sizes are in kb

mice with all four restriction enzymes. NOD, CTS, and ILI mice were different from BALB/c mice with Hind III and Kpn I and also different from C57BL/6 mice with every four enzymes. NON mice were distinct from $\mathrm{BALB} / \mathrm{c}$ mice when Eco RI, Bam HI, and Hind III were used and also distinct from C57BL/6 mice with Bam HI and Hind III. With probe $2(\mathrm{~A} \alpha)$, Hind III and Kpn I generated polymorphism. NOD, CTS, ILI and BALB/c mice showed the same RFLP patterns. NON mice, however, showed distinct patterns from the other ICR-derived mice, $\mathrm{BALB} / \mathrm{c}$, and C57BL/ 6 mice. With probe 3 (EB), NOD, CTS, and ILI mice showed identical band patterns. However, NON, 


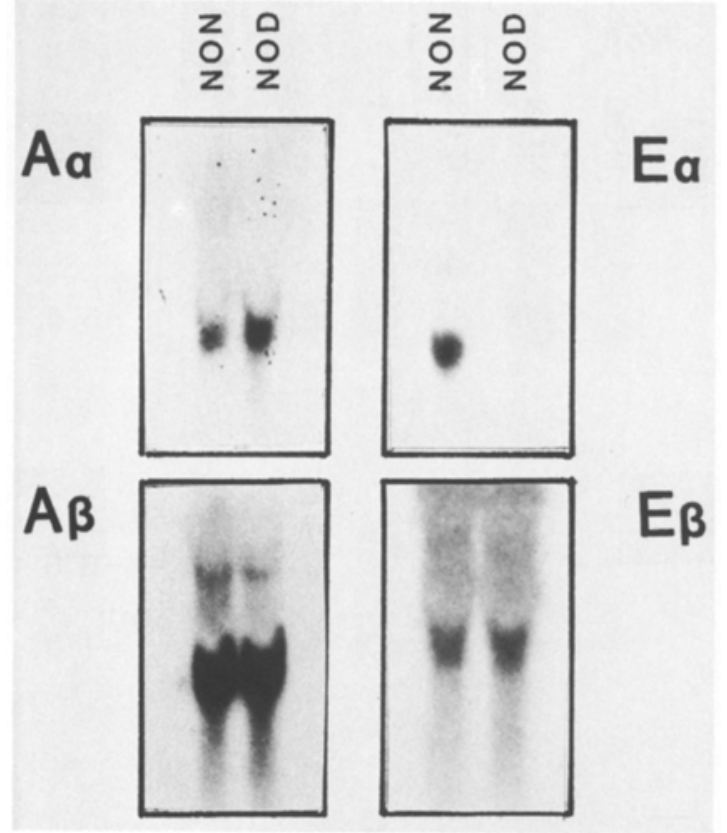

Fig. 3. Northern blot analysis of $A \alpha, A \beta, E \alpha$, and $E \beta$ transcripts in NOD and NON mice. Twenty $\mu \mathrm{g}$ of total RNA per lane was electrophoresed on $1 \%$ agarose formaldehyde gels, blotted, and hybridised with class II probes. A $\alpha$ (probe 2), A $\beta$ (probe 1), E $\alpha$ (probe 4), E $\beta$ (probe 3) indicate probes used

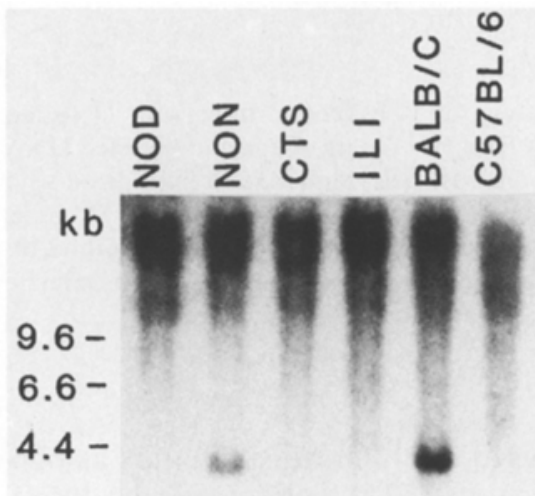

$2.3-$

$1.9-$

BALB/c, or C57BL/6 mice exhibited distinct RFLP patterns, respectively, and were different from NOD, CTS, and ILI mice. With probe $4\left(5^{\prime}\right.$ probe of $\left.E \alpha\right)$ and 5 ( $3^{\prime}$ probe of E $\alpha$ ), NOD, CTS, and ILI mice shared the RFLP patterns with C57BL/6 mice. NON and $\mathrm{BALB} / \mathrm{c}$ mice shared another pattern.

The $E \beta_{2}$ probe, $3.2 \mathrm{~kb}$ Eco RI fragment from cosmid clone 32.1 [13], with the four restriction enzymes, did not generate any polymorphism (data not shown). To analyse RFLP of $A \beta_{2}$ and $A \beta_{3}$, we used probe 1 and a human DP $\beta$ cDNA probe. Probe 1 cross-hybridised with $A \beta_{2}$ [20], and the human DPB probe cross-hybridised with $A \beta_{3}$ [21]. Probe 1 with Pvu II and Pst I, and

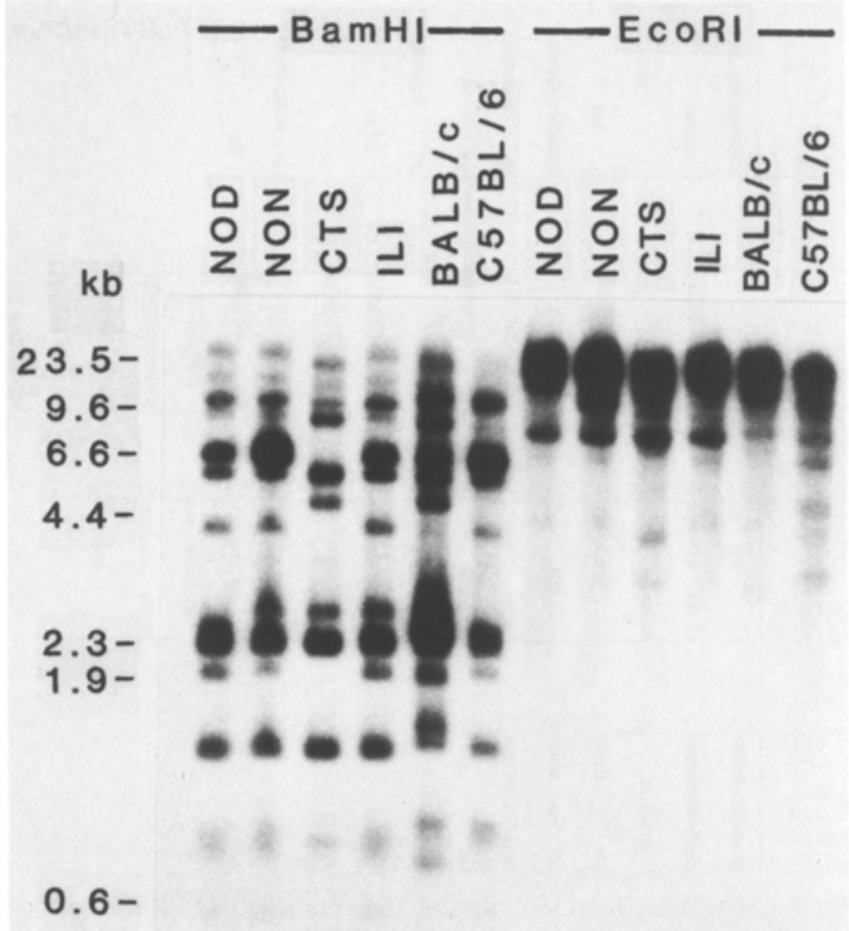

Fig.5. Southern blot analysis of ICR-derived mice with class I probe $\mathrm{L}$ after digestion with Bam HI or Eco RI. Ten $\mu \mathrm{g}$ of DNA was electrophoresed on $0.7 \%$ agarose gels, blotted, and hybridised with the probe. Sizes of DNA marker fragments are shown at the left of the figure

DP $\beta$ probe with Eco RI showed no polymorphism in $A \beta_{2}$ and $A \beta_{3}$, respectively, of the mice studied (data not shown).

Taken together, these results indicate that the NOD class II MHC genes are indistinguishable from those of CTS, and ILI mice as long as the four restriction enzymes, Eco RI, Bam HI, Hind III, and Kpn I, were used. NON class II genes were distinct from those of NOD, CTS, and ILI mice. A $\beta$ and $E \beta$ genes of NOD, CTS, and ILI mice were different from those of $\mathrm{BALB} / \mathrm{c}$ and $\mathrm{C} 57 \mathrm{BL} / 6$ mice. $\mathrm{A} \alpha, \mathrm{A} \beta$, and $\mathrm{E} \beta$ genes of NON mice were also different from those of $B A L B / c$ and $\mathrm{C} 57 \mathrm{BL} / 6$ mice.

\section{Class II major histocompatibility complex gene expression}

NOD and NON mice were examined for class II gene expression. Northern blot analysis indicates that both NOD and NON mice synthesise $A \alpha, A \beta$, and $E \beta$ RNA, and that, while NON mice expressed E $\alpha$ RNA, NOD mice did not (Fig. 3). We have pursued the molecular mechanisms by which this defect in I-E expression is generated. Mice of haplotypes $b$ and $s$ bear a deletion spanning $627 \mathrm{bp}$ which includes the promoter region and the signal peptide exon of the E $\alpha$ gene [22]. With probe 4 , the $5^{\prime}$ region of the $E \alpha$ gene, and the four re- 

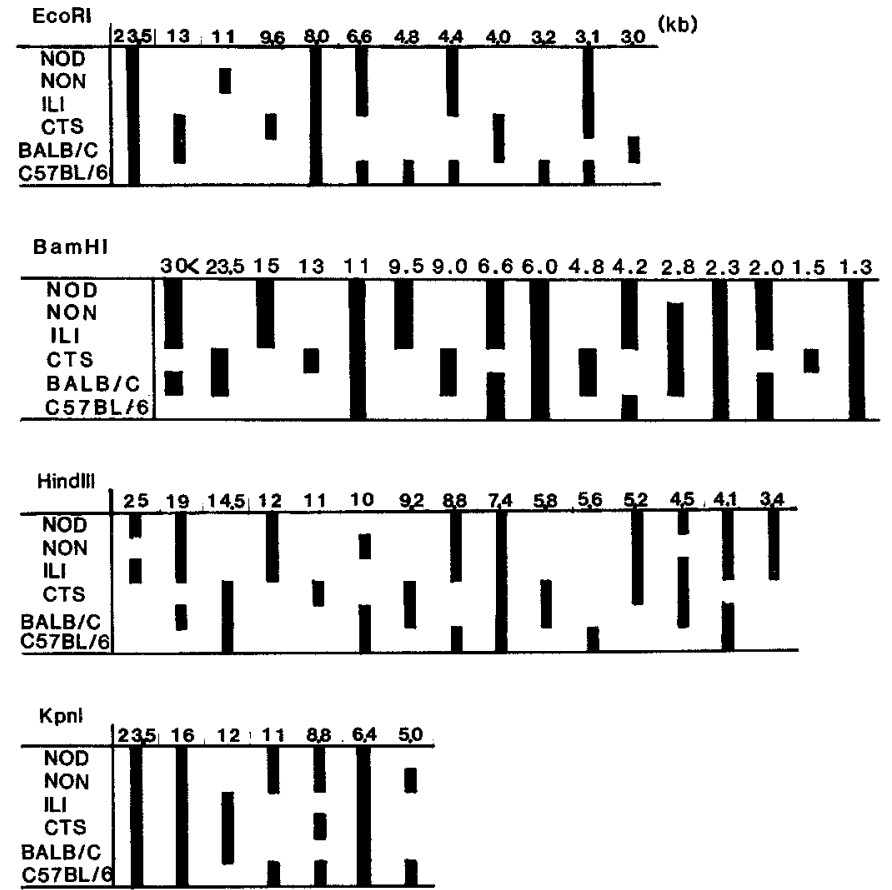

Fig. 6. Schematic representation of the results of RFLP analysis of ICR-derived mice with class I probe L. DNA was digested with each of the restriction enzymes, Eco RI, Bam HI, Hind III, and Kpn I. Black vertical bars ( $\square$ ) indicate hybridised bands

striction enzymes, DNA from NOD mice showed the same RFLP patterns as did those from C57BL/ 6 mice (Table 1). It is conceivable that the failure of the $E \alpha$ gene expression in NOD mice is due to the same deletion of the $\mathrm{E} \alpha$ gene as observed in $\mathrm{C} 57 \mathrm{BL} / 6$ mice.

To confirm our interpretation, we prepared probe 6 which is deleted in mice of haplotype b [23]. Probe 6 hybridised with $4.0 \mathrm{~kb} \mathrm{Kpn}$ I fragments in NON and $\mathrm{BALB} / \mathrm{c}$ mice; however, no hybridised band was evident in NOD, CTS, ILI, and C57BL/6 mice (Fig. 4). It is suggested that NOD, CTS, and ILI mice bear the same deletion spanning the promoter region and the signal peptide exon of the E $\alpha$ gene, as do mice of haplotypes $b$ and $s$ [22-24]. This mutation must prevent transcription of the $\mathrm{E} \alpha$ gene and, hence, functional expression of the $E \alpha-E \beta$ dimer on the cell surface in NOD, CTS, and ILI mice.

\section{Restriction fragment length polymorphism analysis using class I major histocompatibility complex probe}

To analyse RFLP of class I MHC, we prepared probe $\mathbf{L}$ (Fig. 1-(b)) which covers leader peptide, $\mathrm{C}_{1}, \mathrm{C}_{2}$ domains of $\mathbf{L}^{\mathrm{d}}$ gene [15]. Figure 5 showes RFLP patterns using probe L with Bam HI and Eco RI. Since class I probes derived from coding regions cross-hybridise with not only the $\mathrm{K}$ and $\mathrm{D}$ genes but also the Qa genes [25], probe $L$ detected many hybridised bands with every four enzymes. The results are schematically presented

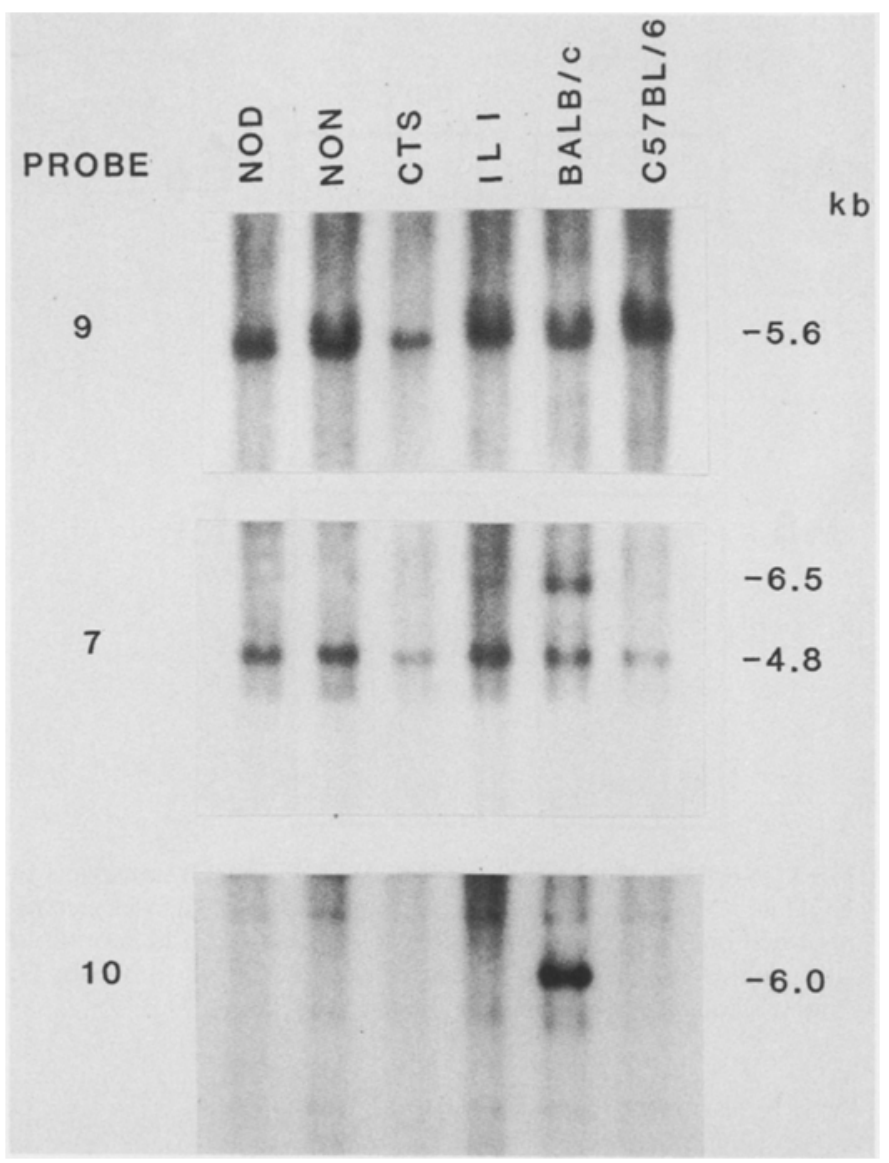

Fig. 7. Southern blot analysis of ICR-derived mice with $D$ region probes after digestion with Bam HI. Ten ug of enzyme-digested DNA per lane was run on $0.7 \%$ agarose gels, blotted, and hybridised with the probes. Probe 9; located in the $5^{\prime}$ flanking sequences of $D^{k}$ gene, probe 7 ; located in the region between $\mathrm{D}^{\mathrm{d}}$ and $\mathrm{D}_{2}^{\mathrm{d}}$ genes, probe 10 ; located in the segment between $\mathrm{D}_{3}{ }^{\mathrm{d}}$ and $\mathrm{D}_{4}{ }^{\mathrm{d}}$ genes. The approximate sizes of the fragments are shown at the right of the figure

in Figure 6. We analysed total hybridised bands as percentage of coincidence of RFLP to NOD class I DNA (see Statistical analysis). The percent coincidence of RFLP to NOD class I DNA of NON, CTS, ILI, $\mathrm{BALB} / \mathrm{c}$, and $\mathrm{C} 57 \mathrm{BL} / 6$ DNA were approximately $88 \%, 39 \%, 90 \%, 57 \%$, and $70 \%$, respectively.

\section{$D$ region gene organisation}

Five D region class I genes, $D^{d}, D_{2}{ }^{d}, D_{3}{ }^{d}, D_{4}{ }^{d}$, and $L^{d}$ have been identified in the $\mathrm{BALB} / \mathrm{c}$ mouse, while only one has been found in mouse strains AKR and $\mathrm{C} 57 \mathrm{BL} / 10$ [14]. To compare the $\mathrm{D}$ region gene organisation in the ICR-derived strains, probes $9,7,10$ and restriction enzymes Bam HI were employed (Fig.7). Probe 9 , isolated from the $5^{\prime}$ flanking sequences of the $\mathrm{D}^{\mathrm{k}}$ gene (Fig. 1-(b)), detected the same restriction fragment in NOD, NON, CTS, ILI, and C57BL/6 DNA as in BALB/c DNA. On the other hand, Probe 7, isolated from the region between $\mathrm{D}^{\mathrm{d}}$ and $\mathrm{D}_{2}{ }^{\mathrm{d}}$ genes (Fig.1-(b)), 


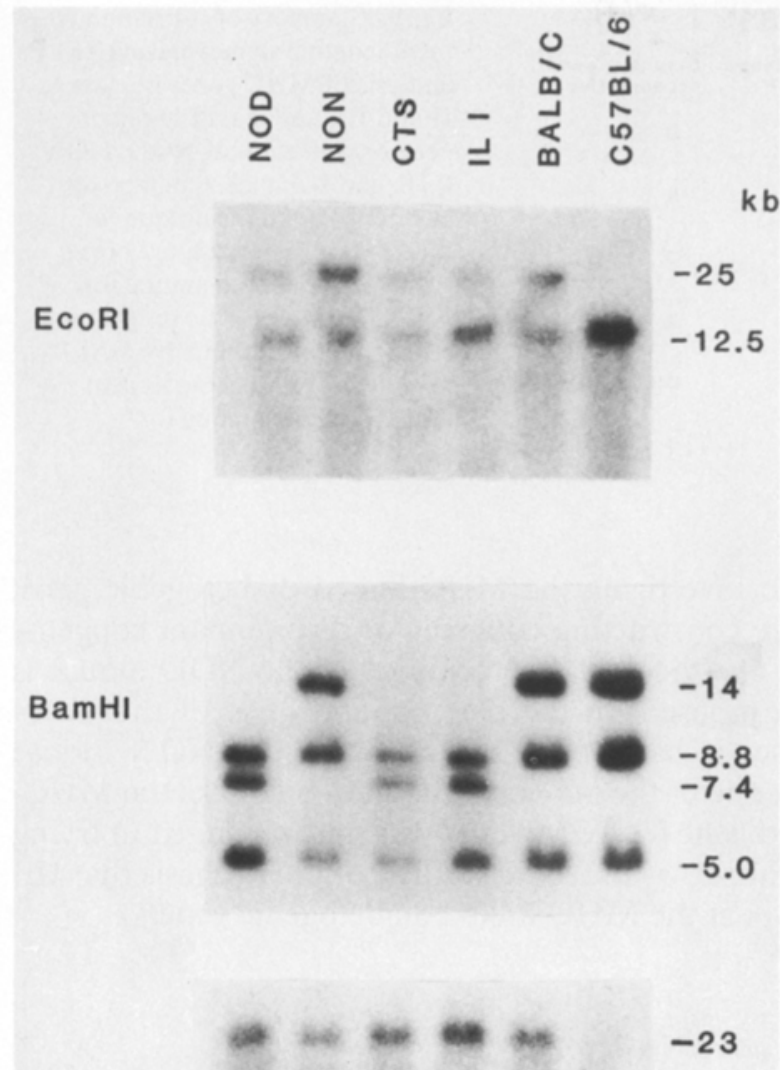

HindIII

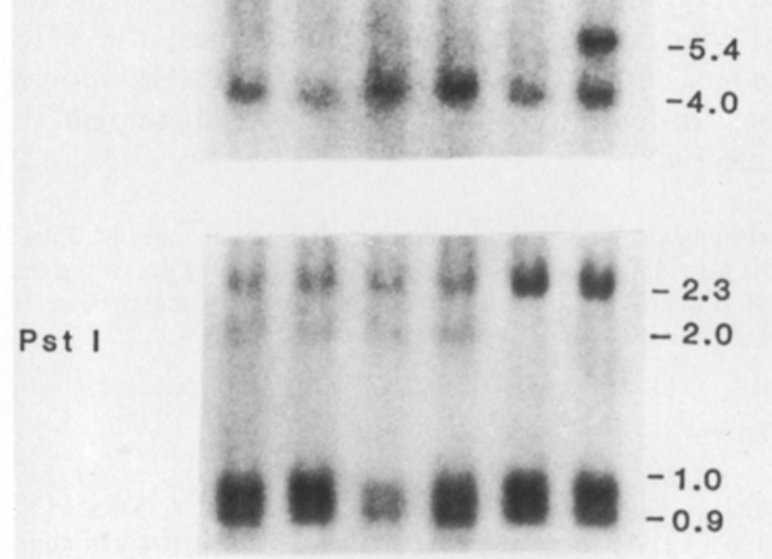

Fig. 8. Southern blot analysis of ICR-derived mice with class III probe 8 after digestion with each of the restriction enzymes Eco RI, Bam HI, Hind III, and Pst I. Ten $\mu \mathrm{g}$ of enzyme-digested DNA per lane was electrophoresed on $0.7 \%$ agarose gels, blotted, and hybridised with the probe. The approximate sizes of the fragments are shown at the right of the figure

picked up a complementary sequence ( $6.5 \mathrm{~kb}$ fragment) only in BALB/c DNA. Probe 7 also picked up the $4.8 \mathrm{~kb}$ fragments in all mice tested since this probe cross-hybridises with a sequence, located in the $3^{\prime}$ flanking sequence of the $\mathrm{L}$ gene [14]. Probe 10 , isolated from the segment between $\mathrm{D}_{3}{ }^{\mathrm{d}}$ and $\mathrm{D}_{4}{ }^{\mathrm{d}}$ gene (Fig. 1-(b)), hybridised with the $6.0 \mathrm{~kb}$ fragment only in BALB/c DNA. These results suggest that the sequences located between the $\mathrm{D}$ and $\mathrm{L}$ genes are absent from NOD,
NON, CTS, ILI and C57BL/6 DNA. It is, therefore, possible that NOD, NON, CTS, and ILI mice contain only a single class I D region gene as do C57BL/ 10 mice.

\section{Restriction fragment length polymorphism analysis using class III probe}

Figure 8 shows RFLP studies using probe 8 (Fig. 1-(c)), which hybridises with $\mathrm{C} 4$ gene as well as Slp gene(s) [16]. Among ICR-derived strains, NOD, CTS, and ILI mice showed the same RFLP patterns. (Eco RI $23 \mathrm{~kb}<$, $12.5 \mathrm{~kb}$; Bam HI $8.8 \mathrm{~kb}, 7.4 \mathrm{~kb}, 5.0 \mathrm{~kb}$; Hind III $23 \mathrm{~kb}$, $4.0 \mathrm{~kb}$; Pst I $2.3 \mathrm{~kb}, 2.0 \mathrm{~kb}, 1.0 \mathrm{~kb}, 0.9 \mathrm{~kb}$ ), but NON mice showed different patterns when Bam HI was used $(14 \mathrm{~kb}, 8.8 \mathrm{~kb}, 5.0 \mathrm{~kb})$. NOD, CTS, and ILI mice were different from BALB/c mice with Bam HI and Pst I, and also different from C57BL/6 mice with Eco RI, Bam HI, Hind III and Pst I. NON mice were distinct from BALB/c mice when Pst I was used. NON mice also distinct from C57BL/6 mice when Eco RI, Hind III, and Pst I were used. Kpn I and Pvu II did not generate any polymorphism among all mice tested (data not shown). Taken together, these results indicate that the class III MHC genes of these mice were divided into four groups: (1) NOD, CTS, and ILI; (2) NON; (3) $\mathrm{BALB} / \mathrm{c}$; and (4) C57BL/ 6 .

\section{Discussion}

In this study, we have performed RFLP studies of MHC genes in NOD mice in comparison with those of NON, CTS, and ILI mice, which are non-diabetic inbred strains but are derived from the same Jcl-ICR mice as NOD mice.

A summary of RFLP analysis using class I, II and III MHC probes and a minimum of four restriction enzymes, and class I D region gene organisation, are schematically presented in Figure 9.

By using class II probes with the four restriction enzymes, Eco RI, Bam HI, Hind III, and Kpn I, NOD mice have been revealed to share RFLP patterns with CTS and ILI mice. A $\beta$ and E $\beta$ RFLP patterns of these mice were different from those obtained not only in BALB/C $\left(\mathrm{H}-2^{\mathrm{d}}\right)$ and $\mathrm{C} 57 \mathrm{BL} / 6\left(\mathrm{H}-2^{\mathrm{b}}\right)$ mice but also in AKR $\left(\mathrm{H}-2^{\mathrm{k}}\right)$ and A.SW $\left(\mathrm{H}-2^{\mathrm{s}}\right)$ mice [19]. In contrast to CTS and ILI mice, NON mice showed totally different RFLP patterns from those of NOD mice, and $A \alpha, A \beta$, and $E \beta$ genes of NON mice are different from those of $\mathrm{b}$ and $\mathrm{d}$ haplotypes. RFLP studies using the class III probe divided these mice into four groups, 1) NOD, CTS, and ILI, 2) NON, 3) BALB/c, and 4) C57BL/ 6.

According to Stephan et al. [14], the D region of BALB/c mice contains five class I genes, $D, D_{2}, D_{3}, D_{4}$, and $\mathrm{L}$; while only one has been found in AKR and C57BL/10 mice. From our results with a low-copy 


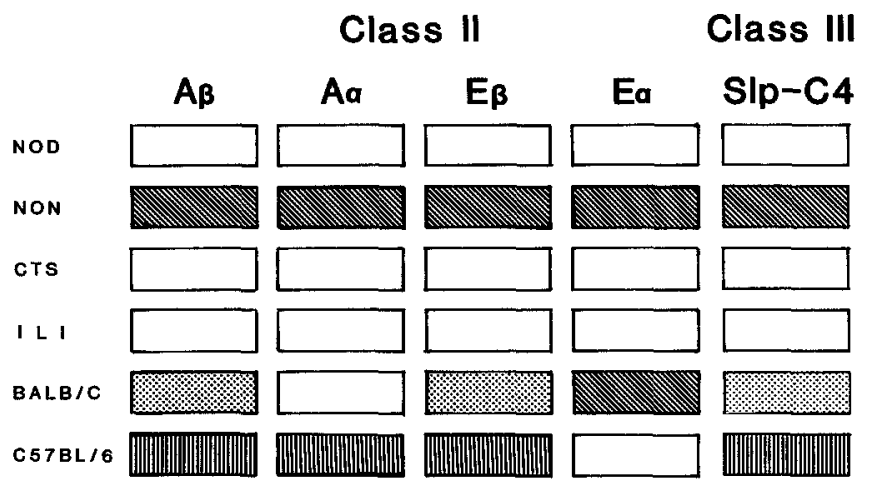

probe and two single copy probes isolated from the $D$ region, we suggest that NOD, NON, CTS, and ILI mice bear only a single class I D region gene. RFLP studies using class I probe L suggest that NOD, NON, and ILI class I DNA are similar, but that CTS mice have distinct class I DNA from those of NOD mice.

Taken together, these results indicate that, although the class I loci of the NOD and ILI mouse were serologically typed as $\mathrm{K}^{\mathrm{d}}$ and $\mathrm{D}^{\mathrm{b}}$ and those of the NON mouse were typed as $\mathrm{K}^{\mathrm{b}}$ and $\mathrm{D}^{\mathrm{b}}$, the inter-class I region, covering the class II and class III genes of NOD, CTS, and ILI mice and those of NON mice derived from the same Jcl-ICR mice, are completely different from each other; and that no $\mathrm{H}-2^{\mathrm{g}}$ type recombination between $\mathrm{K}$ and D loci in NOD, CTS, and ILI mice is evident. Further studies of the MHC genes of the other ICR-derived strains should define the precise events which generated these unique H-2 haplotypes of NOD, CTS, ILI, and NON mice.

Furthermore, these results suggest that the class II and III genes of ILI and CTS mice are identical to those of NOD mice. Although precise characterisation and localisation of the MHC-linked diabetogenic gene(s) in NOD mice have been not yet determined, the possibility exists that ILI and CTS mice, but not NON mice, possess the gene(s). In this case, since ILI and CTS mice are not known to develop insulitis or diabetes, they are presumed not to possess the other genes necessary for development of insulitis and diabetes. This possibility could be confirmed by breeding studies.

It has been suggested that NOD mice lack $\mathrm{E} \alpha$ mRNA [8]. We found that NOD mice, as well as CTS and ILI mice, bear a deletion spanning the promoter region and the signal peptide exon of the E $\alpha$ gene, resulting in failure of the E $\alpha$ gene expression. In contrast to NOD, CTS, and ILI mice, NON mice express the E $\alpha$ gene. Nishimoto et al. [12] reported that the expression of I-E molecules in NOD mice can prevent the development of auto-immune insulitis. However, it has been suggested that the other MHC-linked genes including I-A are involved in the development of insulitis or diabetes [11]. In this context, ILI and CTS mice might be useful for further analysis of the MHC-linked diabetogenic gene(s) of NOD mice.

$\begin{array}{cl}\begin{array}{c}\text { Class } \\ \begin{array}{c}\text { I coincidence } \\ \text { of RFLP }\end{array}\end{array} & \begin{array}{l}\text { D region gene } \\ \text { organization }\end{array} \\ 100 & \text { D } \\ 88 & \text { D } \\ 39 & \text { D } \\ 90 & \text { D } \\ 57 & \text { D,D2,D3,D4,L } \\ 70 & \text { D }\end{array}$

Fig.9. Summary of restriction fragment length polymorphism (RFLP) analysis of MHC genes of class I, II and III, and class I D region gene organisation of NOD, NON, CTS, and ILI mice. Open boxes $(\square)$ : RFLP patterns unique for NOD mice; oblique lined boxes $(\mathbb{B S})$ : RFLP patterns unique for NON mice; dotted boxes (지): RFLP patterns unique for $B A L B / c$ mice; vertical lined boxes (IIII): RFLP patterns unique for C57BL/6 mice

To investigate the MHC-linked diabetogenic gene, we are constructing congenic or recombinant congenic mice in which the H-2 complex of the NOD mouse is superimposed on the back-ground gene of the NON mouse. It has been suggested that the NON mouse bears one of the two insulitis genes but lacks the MHClinked gene [7]. We are also currently engaged in trying to confirm, by breeding studies, our hypothesis that ILI mice bear the MHC-linked diabetogenic gene(s).

\section{Note added in proof}

During preparation of this paper, Ikegami et al. reported that, using monoclonal antibodies, the CTS mouse has similar class II antigens to the NOD mouse but has different class I antigens (Diabetologia 31, 254-258, 1988).

Acknowledgments. We thank M.Steinmetz, T.Shiroishi, and M. Takahashi for providing probes, S. Makino and H. Kato for providing the mouse strains, and M.Shimizu and T.Hori for technical assistance.

\section{References}

1. Makino S, Kunimoto K, Muraoka Y, Mizushima Y, Katagiri K, Tochino Y (1980) Breeding of a non-obese, diabetic strain of mice. Exp Animal (Tokyo) 29: 1-13

2. Fujita T, Yui R, Kusumoto Y, Serizawa Y, Makino S, Tochino Y (1982) Lymphocytic insulitis in a "non-obese diabetic (NOD)" strain of mice: an immunohistochemical and electron microscope investigation. Biomed Res 3: 429-443

3. Kanazawa Y, Komeda K, Sato S, Mori S, Akanuma Y, Takaku F (1984) Non-obese-diabetic mice: immune mechanisms of pancreatic B-cell destruction. Diabetologia 27: 113-115

4. Maruyama T, Takei I, Taniyama M, Kataoka K, Matsuki S (1984) Immunological aspect of non-obese diabetic mice: immune islet cell-killing mechanism and cell mediated immunity. Diabetologia 27: 121-123

5. Yokono K, Shii K, Hari J, Yaso S, Imamura Y, Ejiri K, Ishihara K, Fuji S, Kazumi T, Taniguchi H, Baba S (1984) Production of monoclonal antibodies to islet cell surface antigens using hybridisation of spleen lymphocytes from non-obese diabetic mice. Diabetologia 26: 379-385

6. Yoshida TO, Koide Y, Fujishima Y, Hori T, Masamoto T, Wu CL, Haraguchi S, Nishimura M (1987) Gene modification and autoimmune mechanisms in NOD mouse strain as human 
IDDM model. In: Wigzell $\mathrm{H}$, Kyogoku M (eds) New horizons in animal models for autoimmune diseases. Academic Press, Tokyo, pp 59-67

7. Makino S, Muraoka Y, Kishimoto Y, Hayashi Y (1985) Genetic analysis for insulitis in NOD mice. Exp Animal 34: 425-432

8. Hattori M, Buse JB, Jackson RA, Glimcher L, Dorf ME, Minami M, Makino S, Moriwaki K, Kuzuya H, Imura H, Strauss WM, Seidman JG, Eisenbarth GS (1986) The NOD mouse: recessive diabetogenic gene in the major histocompatibility complex. Science 231: 733-735

9. Prochazka M, Leiter EH, Serreze DV, Coleman DL (1987) Three recessive loci required for insulin dependent diabetes in nonobese diabetic mice. Science 237: 286-289

10. Wicker LS, Miller BJ, Coker LZ, McNally SE, Scott S, Mullen Y, Appel MC (1987) Genetic control of diabetes and insulitis in the nonobese diabetic (NOD) mouse. J Exp Med 165: 1639-1654

11. Acha-Orbea $\mathbf{H}$, McDevitt HO (1987) The first external domain of the nonobese diabetic mouse class II I-A $\beta$ chain is unique. Proc Natl Acad Sci USA 84: 2435-2439

12. Nishimoto H, Kikutani $H$, Yamamura K, Kishimoto T (1987) Prevention of autoimmune insulitis by expression of I-E molecule in NOD mice. Nature 328:432-434

13. Steinmetz M, Minard K, Horvath S, McNicholas J, Srelinger J, Wake C, Long E, Mach B, Hood L (1982) A molecular map of the immune response region from the major histocompatibility complex of the mouse. Nature $300: 35-42$

14. Stephan D, Sun H, Lindahl KF, Meyer E, Hammering G, Hood L, Steinmetz M (1986) Organization and evolution of D region class I genes in the mouse major histocompatibility complex. J Exp Med 163: 1227-1244

15. Evans GA, Margulies DH, Shykind B, Seidman JG, Ozato K (1982) Exon shuffling: Mapping polymorphic determinants on hybrid mouse transplantation antigens. Nature 300:755-757

16. Nonaka M, Nakayama $K$, Yeul YD, Schimizu A, Takahashi M (1985) Molecular cloning and characterization of complementary and genomic DNA clones for mouse C4 and Slp. Immunol Rev 87: 81-99

17. Nasmyth KA (1982) The regulation of yeast mating-type chromatin structure by SIR: an action at a distance affecting both transcription and transposition. Cell 30: 567-578
18. Chirgwin JM, Przybyla AE, MacDonald RJ, Rutter WJ (1979) Isolation of biologically active ribonucleic acid from source enriched in ribonuclease. Biochemistry 18: 5294-5299

19. Steinmetz M, Malissen M, Hood L, Orn A, Maki RA, Dastoornikoo QR, Stephan D, Gibb E, Romaniuk R (1984) Tracts of high or low sequence divergence in the mouse major histocompatibility complex. EMBO J 3: 2995-3003

20. Larhammer DD, Hammerling U, Denaro M, Lund T, Flavell RA, Rask L, Peterson PA (1983) Structure of the murine immune response I-A $\beta$ locus: Sequence of the I-A $\beta$ gene and an adjacent $\beta$ chain second domain exon. Cell 34: 179-188

21. Widera G, Flavell RA (1985) The I region of the C57BL/10 mouse: Characterization and physical linkage to $\mathrm{H}-2 \mathrm{~K}$ of an SB $\beta$ like class II pseudogene, $\psi A$ A $\beta_{3}$ : Proc Natl Acad Sci USA 82: 5500-5504

22. Denbic Z, Ayane M, Klein J, Steinmetz M, Benoist CO, Mathis DJ (1985) Inbred and wild mice carry identical deletions in their E $\alpha$ MHC genes. EMBO J 4: 127-131

23. Hyldig-Nielsen JJ, Schenning L, Hammerling U, Widmark E, Heldin E, Lind P, Servenius B, Lund T, Fravell R, Lee JS, Trowsdale J, Schreier PH, Zablitzky F, Larhammer D, Peterson PA, Rask L (1983) The complete nucleotide sequence of the I-E $\alpha^{d}$ immune response gene. Nucleic Acids Res 11: 5055-5071

24. Mathis DJ, Benoist CO, Williams VEII, Kanter MR, McDevitt HO (1983) Several mechanisms can account for defective E $\alpha$ gene expression in different mouse haplotypes. Proc Natl Acad Sci USA 80: 273-277

25. Steinmetz M, Winoto A, Minard K, Hood L (1982) Clusters of genes encoding mouse transplantation antigens. Cell 28: $489 \backsim 498$

Received: 2 August 1988

and in revised form: 8 December 1988

Dr. Y.Fujishima

Department of Microbiology and Immunology

Hamamatsu University School of Medicine

3600 Handa, Hamamatsu

Japan 